Creative Commons User License: CC BY-NC-ND

Abstracted by: EBSCOhost, Electronic Journals Service (EJS),

Google Scholar, Journal Seek, Scientific Commons,

Food and Agricultural Organization (FAO), CABI and Scopus

http://eoi.citefactor.org/10.11226/v24i3
Journal of Agricultural Extension

Vol. 24 (3) July, 2020

ISSN(e): 24086851; ISSN(Print); 1119944X

http://journal.aesonnigeria.org

http://www.ajol.info/index.php/jae

Email: editorinchief@aesonnigeria.org

\title{
Provisions for Agricultural Extension Services in the Implementation Manuals of the World Bank Assisted Fadama Development Projects in Nigeria: Gaps and Lessons \\ https://dx.doi.org/10.4314/jae.v24i3.12
}

\section{Madukwe, Michael. C}

Department of Agricultural Extension

University of Nigeria, Nsukka

Email:michael.madukwe@unn.edu.ng

$+2348037006968$

\section{Anugwa, Ifeoma}

Department of Agricultural Extension

University of Nigeria, Nsukka

Email: ifeoma.irohibe@unn.edu.ng

Phone: +2348065435735

\section{Abstract}

The study examined the provisions for agricultural extension services in the National Fadama Development Projects in Nigeria. Provisions for extension services were made by the project in the areas of, input support, local development plans and technical assistance. However, certain critical gaps were observed in the provisions for extension services in the projects' operational manuals. The observed gaps were in the areas of the improper selection criteria for facilitators and service providers in terms of educational qualification, limited subject matter coverage, poor format for preparing local development plans and lack of incorporation of more innovative extension approaches in project execution, and misuse and application of the concept of advisory services as an alternative to extension services. In spite of the observed gaps, some positive lessons namely; the matching grant arrangement and user fee approach which ensured the sustainability of the project, diversified menu for extension services which was based on the needs of farmers were learnt. Detailed criteria for measuring the quality of extension services rendered to farmers should be developed and included in future implementation manuals.

Keywords: Provision of agricultural extension services, fadama implementation manuals.

\section{Introduction}

Agricultural transformation and increased productivity are determined to a large extent by the provision of agricultural extension services (DansoAbbeam, Ehiakpor \& Aidoo, 2018). Agricultural extension services are provided to enhance farmers' technical knowledge, farm management skills, and marketing aimed at addressing crop and livestock production issues 
Creative Commons User License: CC BY-NC-ND

Abstracted by: EBSCOhost, Electronic Journals Service (EJS), Google Scholar, Journal Seek, Scientific Commons,

Food and Agricultural Organization (FAO), CABI and Scopus

http://eoi.citefactor.org/10.11226/v24i3
Journal of Agricultural Extension

Vol. 24 (3) July, 2020

ISSN(e): 24086851; ISSN(Print); 1119944X

http://journal.aesonnigeria.org

http://www.ajol.info/index.php/jae

Email: editorinchief@aesonnigeria.org

(Adegebo, Olutegbe, \& Akinbile, 2017). Extension services can be provided by governments or private organizations with the intent of increasing farmers' ability to improve their productivity and income (United States Agency for International Development, (USAID), 2015; Umeh, 2017).

In Nigeria, agricultural extension services are mostly provided by government organizations. However, the existing public agricultural extension service in Nigeria is characterized by many short falls; such as grossly inadequate and untimely funding, very weak research-extension-farmer-inputs linkages system, top-down supply-driven extension approaches, and poor targeting of women, youths and vulnerable groups among others (Osondu, ljioma, Udah . and Emerole, 2015; World Bank, 2020). As a result, the public extension system is unable to respond to the increasingly diversified extension needs of rural clients.

It is noteworthy that over the past few decades, there have been changes in the approaches and performance of agricultural extension services in Nigeria (Lewis, and Watts, 2015; Kuz, Okwoche and Age, 2018; Nwoye, \& Nwalieji, 2019). These changes, may be attributed to the participation of nongovernmental organizations (NGOs), and donors in funding and provision of agricultural extension services (Sinkaiye, Nwserema, \& Ajayi, 2018). One of such projects is the Fadama Development Project, supported by the World bank. The project created opportunities for introducing demand-driven and pluralistic extension services funded by non-public sources (National Fadama Coordination Office, 2017; World, Bank, 2020).

The expectation was that the project with a major objective of reforming agricultural extension principle and practice should have an elaborate and clearly articulated provisions for implementation of extension activities in the project manuals. This raises the general question of what was provided in the project manuals for the implementation of agricultural extension practices? How comprehensive was these provisions to guide field implementation? Specifically, the study

- examined the provisions for agricultural extension services in the implementation manuals of the NFDP;

- identified gaps in the provision for extension services in the NFDP; and

- identified lessons emanating from the provision for agricultural extension services under the NFDP.

The approach involved a review of the Fadama Project Implementation Manuals (PIMs), Project Appraisal Documents (PADs), World Bank, Federal Ministry of Agriculture and Rural Development (FMARD) and African Development Fund (ADF) reports in Nigeria. (latitude 4 to $14 \mathrm{~N}$, longitude 4 to $15 \mathrm{E})$. 
Creative Commons User License: CC BY-NC-ND

Abstracted by: EBSCOhost, Electronic Journals Service (EJS), Google Scholar, Journal Seek, Scientific Commons,

Food and Agricultural Organization (FAO), CABI and Scopus

http://eoi.citefactor.org/10.11226/v24i3
Journal of Agricultural Extension

Vol. 24 (3) July, 2020

ISSN(e): 24086851; ISSN(Print); 1119944X

http://journal.aesonnigeria.org

http://www.ajol.info/index.php/jae

Email: editorinchief@aesonnigeria.org

\section{Overview of the National Fadama Development Project}

The project was mainly funded by the World Bank, with counterpart funding by the federal and benefiting state governments (National Fadama Coordination Office, 2017). The NFDP was implemented in all the 36 states of the federation and the Federal Capital Territory (FCT).

The main objective of the project was to sustainably increase the incomes of fadama users. The project also hoped to sustain the increase of incomes of fadama resource users by directly delivering resources to the beneficiary rural communities, efficiently and effectively, and empowering them to collectively decide on how resources are allocated and managed for their livelihood activities and to participate in the design and execution of their sub projects (National Fadama Coordination Office, 2017; Agunloye, Fasina, \& Akinnagbe, 2017; Umeh, 2017). The Fadama projects were implemented in three phases, Fadama I, II III and Fadama 111 Additional Financing (AF).

According to the World Bank (2016a), Fadama I was designed to develop small-scale irrigation and productive support to beneficiary farmer groups in selected Nigerian states in form of irrigation management, cost recovery, and access to credit, marketing, and other services. Fadama II, launched in 2003, introduced the concept of community-driven development (CDD) model to Nigeria's rural development effort and helped institutionalize local stakeholder engagement in community decision-making. The primary objective of Fadama III was to support the growth of non-oil sectors through the development of productive infrastructure that will enhance agricultural productivity and the diversification of livelihoods. It involves building participating communities' social capital and their capacity to provide rural services to the poor with the aim of sustainably increasing the incomes of users of rural land and water resources in Nigeria (World Bank, 2016a).

Fadama III had two additional finance projects. The first additional finance project, implemented between July 2013 and December, 2017, focused on improving farm productivity performance of clusters of farmers engaged in rice, cassava, sorghum and horticulture in six selected states (Anambra, Enugu, Kano, Kogi, Lagos and Niger) with high potential. The aim was to attract private investment in processing and milling, and other commercial aspects of agriculture around nucleus farms, with associated small-holder linkages such as out-grower schemes and contracting farming arrangements (National Fadama Coordination Office, (NFCO, 2015). The second additional financing project, implemented between December 2017 and December, 2019 , focused on increasing the incomes for users of rural lands and water resources in a sustainable manner, and to contribute to restoration of the livelihoods of conflict affected households in the six North-eastern states affected by Boko Haram insurgency in Nigeria. The essence of this was to 
Creative Commons User License: CC BY-NC-ND

Abstracted by: EBSCOhost, Electronic Journals Service (EJS), Google Scholar, Journal Seek, Scientific Commons,

Food and Agricultural Organization (FAO), CABI and Scopus

http://eoi.citefactor.org/10.11226/v24i3
Journal of Agricultural Extension

Vol. 24 (3) July, 2020

ISSN(e): 24086851; ISSN(Print); 1119944X

http://journal.aesonnigeria.org

http://www.ajol.info/index.php/jae

Email: editorinchief@aesonnigeria.org

support the restoration of food security and agricultural livelihood activities in the region (World Bank, 2016b).

In order to achieve the objectives of the programme, multi-stakeholders' institutions were established at various levels. At the national level there exist the National Fadama Coordination Office (NFCO), the National Fadama Technical Committee (NFTC). At the state level were the State Fadama Development Committee (SFDC) and the State Fadama Technical Committee (SFTC). At the local government level were, the Local Fadama Development Committee and the Local Fadama Desk (LFD. At the community level the project had the Fadama Management Committee (FMC), the Fadama User Group (FUG) and the Fadama Community Association (FCA) for effective and efficient implementation of the project (National Fadama Coordination Office, (NFCO, 2015).

The main functions of the fadama development officials at the federal, state and local government area levels were planning, extension, monitoring, management and supervision. Facilitators were hired by the state fadama development team (SFDT) to organize the fadama users' groups and guide them through the intensive processes of decision-making using a wide range of participative techniques (Adegebo, Outage, \& Akinbile, 2017). These facilitators, in addition to other things, carried out extension services to the beneficiary farmers.

\section{Provisions for Agricultural Extension Services in the NFDP}

The NFDP project made provisions for agricultural extension services in the following areas:

Advisory services: Advisory services as used by the NFDP was designed to guide and persuade farmers to adopt more productive and profitable practices in their income generating activities using educational means (Adegebo, Olutegbe, \& Akinbile, 2017). These advisory services ranged from advice for small-scale enterprise development, to marketing information, access to and use of credit and farm inputs, among others (National Fadama Coordination Office, 2017).

The advisory services were further extended to include newer areas such as: production diversification and quality improvement; conflict resolution and environmental awareness; improving access to and returns from use of farm inputs as well as the provision of market information to input suppliers and users; and enterprise management support (World Bank, 2016a). Under the Fadama III additional financing, provision was made for the procurement of advisory services to transfer know-how on proper utilization of factors of production (fertilizers, improved seeds and agricultural machinery), including advice on the associated downstream activities (National Fadama Coordination Office, (NFCO, 2015). Further advisory service provided was the 
Creative Commons User License: CC BY-NC-ND

Abstracted by: EBSCOhost, Electronic Journals Service (EJS), Google Scholar, Journal Seek, Scientific Commons,

Food and Agricultural Organization (FAO), CABI and Scopus

http://eoi.citefactor.org/10.11226/v24i3
Journal of Agricultural Extension

Vol. 24 (3) July, 2020

ISSN(e): 24086851; ISSN(Print); 1119944X

http://journal.aesonnigeria.org

http://www.ajol.info/index.php/jae

Email: editorinchief@aesonnigeria.org

integration of nutritional advice/information to extension delivery (World Bank, 2016b).

The beneficiaries of the advisory services were economic interest groups and rural entrepreneurs which included individual farmers and their organizations, women groups, pastoralists, fishermen and women, small-scale processors, traders, input stockists, nursery entrepreneurs, commodity groups, and farm tool manufacturers. Other clients include bodies and institutions representing public interests at various levels such as village authorities, local governments and state governments who would benefit from support for services of broader public interest such as the facilitation and mediation in fadama resource use planning, building private sector input supply chains and adaptive research on specific issues of local and state interests.

Input support: Provision of input support was a high priority, since many of the rural communities do not have assured and reliable access to critical factors of production of good quality on a timely basis (World Bank, 2016a). This facility was adopted to share the risks involved in the adoption of a new technology by farmers, to enhance their purchasing power and hence financial capability to purchase farm inputs and to build their savings to finance future purchases. The farm inputs included crop production (seed and seedlings; fertilizers and manure; and agro-chemicals), livestock production (foundation stock, feeds, drugs), pastoralist (pasture seeds), fisher folks (fingerlings; feed, drugs) and agroforestry (parent stock, drugs, feed).

In addition, during the phase of the additional financing of the Fadama III project, the productivity improvement of the selected rice, cassava, sorghum and horticulture value chains was supported by upgrading the parent project's paper input voucher program to the use of e-wallet platform to deliver improved seeds and fertilizers to beneficiaries. This way, the Fadama III additional financing took advantage of the reforms (liberalization) in the input sector where private seed and fertilizer companies including agro-dealers deliver inputs directly to farmers. The objective of this support was to ensure timely and equitable access (especially for women farmers) to these critical inputs in good quantity and quality to the production clusters in the project intervention areas where low yields were the binding constraint (World Bank, 2016a). Also, smallholder farmers who benefitted from the second additional financing project in the Northeast were supported with critical inputs to ensure direct support for their livelihoods beyond subsistence farming and promoting value chain (World Bank, 2016b).

Local development plans: The project adopted a demand- driven approach whereby all users of fadama resources were encouraged to develop participatory and socially - inclusive local development plans (LDPs) as a condition to access the funds. (ADF, 2020). In the LDP, they were expected to articulate and decide on which advisory services they needed to enable them 
Creative Commons User License: CC BY-NC-ND

Abstracted by: EBSCOhost, Electronic Journals Service (EJS), Google Scholar, Journal Seek, Scientific Commons,

Food and Agricultural Organization (FAO), CABI and Scopus

http://eoi.citefactor.org/10.11226/v24i3
Journal of Agricultural Extension

Vol. 24 (3) July, 2020

ISSN(e): 24086851; ISSN(Print); 1119944X

http://journal.aesonnigeria.org

http://www.ajol.info/index.php/jae

Email: editorinchief@aesonnigeria.org

increase their productivity. The various economic interest groups, were expected to participate actively in the development of the LDPs and in their implementation.

The LDPs comprised the following provisions for extension services:

a. a list of advisory needs in terms of production and marketing constraints and opportunities;

b.an agreed mechanism to manage and resolve conflicts, especially, those concerning fadama users; and

c. a plan for training and building the capacity of FCAs in financial management and other aspects of organization and management of the associations.

Technical assistance: The project made provisions for strengthening the capacity of the Agricultural Development Programme (ADPs) of the states to provide knowledge and technology to meet the goals of improving quality and value added and increase market access. This aimed at enhancing the efficiency and effectiveness of the ADPs in the provision of extension services to the farming community, including pastoralists and fisher folks. (Hima, Santibanez, Roshan, and Lomme, 2016).

The ADP offices were supported by the project to: (a) provide support to advisory service providers by providing specialized technical assistance, training, experience-sharing, and knowledge-exchange opportunities to them in the area of specific agricultural technologies; (b) ensure quality assurance of advisory services by providing ADPs with a small computerized research laboratory with full internet connectivity to certify service providers and ensure that the advisory services delivered to project beneficiaries met established quality standards; (c) training of facilitators through the ADP on formulation of demand for advisory services; (d) training of extension staff by the National Food Reserve Agency (World Bank, 2020).

\section{Provision of Extension Service in the Implementation Process}

The provision of extension services under the NFDP was that the ADPs were directly contracted to provide the advisory services relating to agricultural production and irrigation. in which they have a comparative advantage (World bank, 2020). On the other hand, other advisory services such as information on prices and commodity markets; establishment of a small-scale enterprise; and HIV/AIDS issues, among others, were to be acquired from private organizations such as NGOs, producer organizations, research institutions and private entrepreneurs (ADF, 2020).

However, the state fadama development team (SFDT), created within each participating ADP, was saddled with the responsibility of screening requests for advice from the different service providers and determine the most appropriate category of service providers who would engage in the various project intervention. They were also required to link the service providers to 
Creative Commons User License: CC BY-NC-ND

Abstracted by: EBSCOhost, Electronic Journals Service (EJS), Google Scholar, Journal Seek, Scientific Commons,

Food and Agricultural Organization (FAO), CABI and Scopus

http://eoi.citefactor.org/10.11226/v24i3
Journal of Agricultural Extension

Vol. 24 (3) July, 2020

ISSN(e): 24086851; ISSN(Print); 1119944X

http://journal.aesonnigeria.org

http://www.ajol.info/index.php/jae

Email: editorinchief@aesonnigeria.org

the FRUGs for possible contracting for such services under project support (ADF, 2020).

The project implemented advisory services that were pluralistic and demanddriven in approach based on the beneficiaries felt needs. that are germane to the successful implementation of their sub-projects (National Fadama Coordination Office (NFCO, 2017). The demand-driven advisory service was provided by both the public and private service providers in which the beneficiaries paid $10 \%$ of the cost while $90 \%$ was paid by the project (NFCO, 2015). Fadama users were to be assisted to gain access to a diversified menu of farm and enterprise advisory services and select their service providers among the registered and certified providers. They were also expected to determine the content and scope of the advisory service that was to be provided to them.

The procedure for the provision of the input support was based on the condition that the benefiting farmer request and use advisory services that would ensure effective and efficient use of the inputs.

The procedure for the execution of the local development plan (LDP) was that a local government fadama development team (LGFDT) from the participating LGA were to be trained on participatory planning and implementation tools for community-driven development activities, including rural infrastructure and monitoring and evaluation. Thereafter, they trained facilitators in participatory planning whose function was to assist the FRUGs identify and prioritize advisory services (World Bank, 2020).

Furthermore, the organized fadama community associations (FCAs) undertook a participatory needs assessment (PNA), which served as the information source book for launching the local development planning process (National Fadama Coordination Office, 2017).

\section{Gaps in the Provisions for Agricultural Extension Services in the NFDP}

In spite of the elaborate documentation of activities for the effective implementation of extension services in the Fadama project documents, there were some observed loopholes that could hinder the success of the project. They include the following:

\section{Confusion arising from the use of the terms "extension" and "advisory} services". There was interchangeability in the use of the terms "extension" and "advisory" services in the project implementation manuals. The mix-up is also common in literature (Berthe, 2015; Diesel, and Miná, 2016; Laurens, 2020). However, it is important to note that there is a clear distinction between the two terms. While extension is generic term of a service and learning process which helps people to solve their own problems, (Knierim, Boenning, Caggiano, Cristóvão, Dirimanova, Koehnen, et al, 2015; Altalb, Filipek, Skowron, 2016; Kuehne, Llewellyn, Pannell, Wilkinson, Dolling, 
Creative Commons User License: CC BY-NC-ND

Abstracted by: EBSCOhost, Electronic Journals Service (EJS), Google Scholar, Journal Seek, Scientific Commons,

Food and Agricultural Organization (FAO), CABI and Scopus

http://eoi.citefactor.org/10.11226/v24i3
Journal of Agricultural Extension

Vol. 24 (3) July, 2020

ISSN(e): 24086851; ISSN(Print); 1119944X

http://journal.aesonnigeria.org

http://www.ajol.info/index.php/jae

Email: editorinchief@aesonnigeria.org

Ouzman, et al, 2017), advisory services is an approach used in organizing and implementing effective extension services

(Dockès, Chauvat, Correa, Turlot, and Nettle, 2019; Eastwood, Ayre, Nettle, and Dela, 2019).

Hence, the interchangeability in the use of these two concepts should be avoided as it leads to ambiguity and confusion among extension workers in many countries. This type of confusion usually results in the inefficient use of available resources, thus exposing the country to the danger of giving priority to extension structures over functions and of neglecting to identify how extension interacts with other services within a particular social context. What is at play here is thus, Knowledge, as defined by the fund provider.

Selection criteria for facilitators and service providers: It was observed that the project did not make provisions for criteria in selecting facilitators and service providers who would implement advisory services in terms of educational qualifications and experience. Ideally, service providers for the agricultural extension component of the project should be qualified extension personnel, with educational background in agricultural extension, who possess the requisite knowledge and technical, management, marketing and programme delivery skills needed to effectively implement extension activities.

The implication of not stipulating the criteria for the undefined selection of extension personnel as facilitators created opportunity were facilitators with little or no background in agriculture extension could be recruited. Although it was specified that the service providers who were drawn from the extension arm of ADP as well as other public and private institutions would undergo series of in-service training in order to carry out their activities efficiently, their basic pre-employment educational qualification cast doubt on the quality of extension services delivered to project beneficiaries. Further credence to this was laid by Agunloye, Fasina, \& Akinnagbe (2017) that most of the Fadama facilitators in Nigeria had no extension orientation and this affected their effectiveness in carrying out extension activities.

Subject matter coverage: Although virtually all aspects of agriculture and environment (such as crops, livestock, fisheries, agro-forestry, post-harvest enterprises and sustainable agricultural practices) were specified as advisory services to be provided to the FCAs/FUGs, cross cutting issues such as climate change, hygiene, health care, family planning and indigenous knowledge technologies were not pronounced. The aforementioned crosscutting issues could negatively affect the agricultural productivity of beneficiary farmers.

Measures for coordinating extension activities: While some institutional measures were specified for the proper coordination of the extension activities under the NFDP, measures that could checkmate poor monitoring and 
Creative Commons User License: CC BY-NC-ND

Abstracted by: EBSCOhost, Electronic Journals Service (EJS), Google Scholar, Journal Seek, Scientific Commons,

Food and Agricultural Organization (FAO), CABI and Scopus

http://eoi.citefactor.org/10.11226/v24i3
Journal of Agricultural Extension

Vol. 24 (3) July, 2020

ISSN(e): 24086851; ISSN(Print); 1119944X

http://journal.aesonnigeria.org

http://www.ajol.info/index.php/jae

Email: editorinchief@aesonnigeria.org

execution of extension activities in the form of sanctions were not specified. This could result to elite capture, political manoeuvres, delay in both the disbursement of funds by the project and beneficiary contribution by the FUGs and unethical conduct of facilitators. (Badiru, 2015; Danladi, 2015).

Changing format for preparing local development plans: It was observed that the format for preparing the local development plan was not specified even though the contents were specified in the PIM. Throughout the project life, there were different variants of the local development plan formats across states. This created confusion and frustration among recipients. Ideally, there should have been a clear standard format for preparing and presenting the LDP in order to ensure uniformity and avoid deviations from what was expected.

\section{Lessons from the Provision for Agricultural Extension Services in the NFDP}

Generally, the provisions for extension services as reflected in the fadama project document were extensive in addressing the objectives of the project to a great extent. Thus, positive lessons emanating from the reviews of the provision for agricultural extension services in the NFDP which could help future development initiatives are as follows:

Clarity and unambiguity in the use of words and terms. Use of agricultural extension, a well-understood concept, instead of advisory services which is an approach to agricultural extension should be avoided. There is the increasing practice of donor agencies introducing words into development lexicon that leads to confusion during implementation. It may be recalled that the use of the term "training and visit" (T\&V) extension system in Nigeria and elsewhere, was made popular by the World bank, when in theory and practice the T\&V was only an extension strategy and not a system. An agricultural extension system is a service with the following characteristics:

- A legal or legislated framework for operation

- continuous direct link to a source of critical mass of new agricultural technology

- continuous direct link with training institution

- a dedicated source of critical funding

- capacity for procuring, processing and adapting agricultural technology

- capability for disseminating agricultural technology directly to farmers

- Identifiable organizational structure

- Separate field extension staff

An agricultural extension strategy usually will fall short of one or more of the above characteristics and is designed to serve as an interim measure to correct specific deficiencies in an existing extension system. Examples of extension strategies in Nigeria include the training and visit $(\mathrm{T} \& \mathrm{~V})$, special 
Creative Commons User License: CC BY-NC-ND

Abstracted by: EBSCOhost, Electronic Journals Service (EJS), Google Scholar, Journal Seek, Scientific Commons,

Food and Agricultural Organization (FAO), CABI and Scopus

http://eoi.citefactor.org/10.11226/v24i3
Journal of Agricultural Extension

Vol. 24 (3) July, 2020

ISSN(e): 24086851; ISSN(Print); 1119944X

http://journal.aesonnigeria.org

http://www.ajol.info/index.php/jae

Email: editorinchief@aesonnigeria.org

programme on food security, (SPFS), Fadama, and Sasakawa Global 2000, among others.

The advisory services component of the project was concerned with mainly diversified problem-solving services that are responsive to production, processing, marketing and supply chain management needs of fadama users. Future agricultural programmes or projects should provide a diversified menu of extension services based on the needs of the project beneficiaries.

The project introduced the user-fee approach that helped in promoting pluralistic extension service delivery with fadama beneficiaries contributing some funds for the procurement of extension services. In order to maintain the sustainability of extension services in future projects, it is important to adopt the matching grant arrangement as it was obtainable in the fadama project in which farmers made a contributory payment for the extension services they received.

The capacity of the ADPs to provide extension services to the fadama farmers was strengthened by matching the farmers' needs with available (on-shelf) technologies and interventions packaged by the research institutes. Thus, future agricultural extension programme should conduct a comprehensive needs assessment to ascertain farmer's priorities before determining the types of extension services that would be provided for them.

Rather than provide pre-selected menus of extension services, the project followed a bottom-up demand-driven approach wherein beneficiaries themselves procured relevant extension services to help them in their selected livelihood. Thus, the demand-driven and bottom-up approach should be adopted by future agricultural projects.

The design of the Fadama project has embraced a model of trial, error, and adaptation in the provision of extension services. From piloting targeted smallscale FUGs with extension services using centrally led, top-down approaches to introducing fundamentally new mechanisms for locally led participatory approach in selecting and paying for extension services, the project has been a laboratory of experiments. Future projects should adopt this process of adaptive learning so as to encourage innovation and enhance project results and sustainability.

The Fadama projects was a clear example of how country-level projects can benefit from international experience. The broad acceptance of the emerging CDD model within Nigeria resulted in part from information gathered on how similar projects had succeeded in other environments, together with careful tailoring to the Nigerian context and use of existing institutional arrangements. Other projects should incorporate successful reforms in extension approach used in similar projects elsewhere. 
Creative Commons User License: CC BY-NC-ND

Abstracted by: EBSCOhost, Electronic Journals Service (EJS), Google Scholar, Journal Seek, Scientific Commons,

Food and Agricultural Organization (FAO), CABI and Scopus

http://eoi.citefactor.org/10.11226/v24i3
Journal of Agricultural Extension

Vol. 24 (3) July, 2020

ISSN(e): 24086851; ISSN(Print); 1119944X

http://journal.aesonnigeria.org

http://www.ajol.info/index.php/jae

Email: editorinchief@aesonnigeria.org

An effective institutional structure at the local level was critical to organizing community participation and engagement. The core organizational element of Fadama lay in the formation of stakeholder groups according to their interests, a participatory process that helped build social capital, local governance, and community decision-making capacity, thereby enhancing the sustainability of outcomes. Hence, other projects should ensure an efficient institutional structure with active participation of all stakeholder groups so as to enhance the sustainability of the project outcomes.

The project invested heavily in capacity building, recruiting staff from the private and public sectors to, paying them competitively, and deploying a large network of trained facilitators to provide advisory services to farmers to participating community groups around the country. Thus, other projects should borrow a leaf by ensuring that the capacities of their projects staff are built so as to ensure an efficient and effective extension service delivery.

Like the Fadama project, future agricultural extension projects should have flexible delivery mechanisms which will allow solutions to be tailored to diverse local contexts, strengthening local-level decision making and reducing political interference.

\section{Conclusion and Recommendations}

The provisions for extension services as outlined in the operational manual of the Fadama projects stand out as a pragmatic model with attributes of pluralism, demand-driven, innovativeness, accountability and cost effectiveness. There was comprehensive incorporation of extension reforms in areas such as capacity to build on existing knowledge of local conditions, to pilot and learn before scaling up, to incorporate and test global practices, and to build important new institutional structures at the local level. Its provision for extension services has come of age through a long process of adaptation and innovation.

The design of the agricultural extension aspect of the Fadama project has the potential to improve the welfare of smallholder farmers, reduce rural poverty and increase food production. As the project evolved, its objectives and implementation modalities were refined to reached an advanced level of sophistication. The benefit of the Fadama experience is that it has been iterative, allowing a process of learning from predecessor projects and adaptation to new challenges.

The release of counterpart funds by both the state and federal government as well as beneficiary farmers should have timeline and sanctions for violation. Timely provision of funds will help to facilitate the effective implementation of extension activities. 
Creative Commons User License: CC BY-NC-ND

Abstracted by: EBSCOhost, Electronic Journals Service (EJS), Google Scholar, Journal Seek, Scientific Commons,

Food and Agricultural Organization (FAO), CABI and Scopus

http://eoi.citefactor.org/10.11226/v24i3
Journal of Agricultural Extension

Vol. 24 (3) July, 2020

ISSN(e): 24086851; ISSN(Print); 1119944X

http://journal.aesonnigeria.org

http://www.ajol.info/index.php/jae

Email: editorinchief@aesonnigeria.org

Detailed criteria for measuring the quality of extension services rendered to farmers should be developed and included in the implementation manual. Such criteria should include indicators for measuring the effectiveness of extension services provided to the farmers.

A minimum required educational qualification of a degree in agricultural extension should be set as criteria for the selection of facilitators of extension activities. Thus, stringent provisions should be made to ensure that only welltrained extension officials who are trained to understand and disseminate the much-needed technical knowledge to farmers are recruited.

The extension services provided to farmers should be expanded to include emerging cross-cutting issues such as climate change, food security, use of online facilities and gender related issues. This will in no small measure help farmers to be more resilient to such risks associated with their agricultural production activities.

\section{References}

Adegebo, S., Olutegbe, N., and Akinbile, L. (2017). Effect of privatisation of agricultural extension services on productivity of fadama III beneficiaries in Oyo State, Nigeria. Journal of Agricultural Extension, $s$ 21(3). Pp 152-161.

African Development Fund, ADF (2020). Fadama development project appraisal report. https://projectsportal.afdb.org/dataportal/VProject

Agunloye, A.O., Fasina, O.O. and Akinnagbe, O.M. (2017). Effects of national fadama III programme on the scope and scale of beneficiaries' farming activities in South West Nigeria. Journal of Agricultural Extension, 21 (2), 79 90.

Altalb, A.A.T., Filipek, T. Skowron, P.(2016). The role of agricultural extension in the transfer and adoption of agricultural technologies. Asian Journal of Agriculture and Food Sciences (ISSN: 2321 - 1571) Volume 03 (05),500-507

Badiru, I. (2015). Sustainability of the benefits derived from fadama II critical ecosystem management project in Eriti Watershed of Ogun State. Journal of Agricultural Extension, 19(2),136-146.

Berthe, A (2015). Extension and Advisory Services Rural Extension Services for Agricultural Transformation. Background Technical Paper: Feeding Africa, 21-23 October 2015. https://www.afdb.org/fileadmin/uploads/afdb/Documents/Events/Dak Agri2015/Extension and Advisory Services 
Creative Commons User License: CC BY-NC-ND

Abstracted by: EBSCOhost, Electronic Journals Service (EJS), Google Scholar, Journal Seek, Scientific Commons,

Food and Agricultural Organization (FAO), CABI and Scopus

http://eoi.citefactor.org/10.11226/v24i3
Journal of Agricultural Extension

Vol. 24 (3) July, 2020

ISSN(e): 24086851; ISSN(Print); 1119944X

http://journal.aesonnigeria.org

http://www.ajol.info/index.php/jae

Email: editorinchief@aesonnigeria.org

Danladi, K. (2015). A study of the use of mobile phones for participatory extension services in the Gombe State Fadama Project. (Masters thesis) Ahmadu Bello University, Zaria. Retrieved on 16/7/2016 from: kubanni.abu.edu.ng

Danson-Abbeam, G., Ehiakpor, D.S. and Aidoo, R. (2018). Agricultural extension and its effect on farm productivity and income: insight from Northern Ghana. Agriculture and Food Security, 7, 74. DOI: https://doi.org/10.1186/s40066$\underline{018-0225-x}$

Diesel, V., and Miná, D. (2016). The Brazilian experience with agroecological extension: A critical analysis of reform in a pluralistic extension system. The Journal of Agricultural Education and Extension 22: 415-433. doi: 10.1080/1389224X.2016.1227058

Dockès, A. C., S. Chauvat, P. Correa, A. Turlot, and R. Nettle. (2019). Advice and advisory roles about work on farms. A review. Agronomy for Sustainable Development 39: 2. doi: 10.1007/s13593-018-0547

Eastwood, C., M. Ayre, R. Nettle, and B. Dela Rue. (2019). Making sense in the cloud: Farm advisory services in a smart farming future. NJAS - Wageningen Journal of Life Sciences 90-91: 100298. doi: 10.1016/j.njas.2019.04.004

Hima, Halimatou; Santibanez, Claudio; Roshan, Sabrina; Lomme, Roland. (2016). The Nigeria Fadama National Development Series : How to Build a Pilot into a National Program through Learning and Adaptation. World Bank, Washington, DC. (C) World Bank. https://openknowledge.worldbank.org/handle/10986/24413.

Knierim, A., K. Boenning, M. Caggiano, A. Cristóvão, V. Dirimanova, T. Koehnen, P. Labarthe, and K. Prager. (2015). The AKIS concept and its relevance in selected EU member states." Outlook on Agriculture 44: 29-36. doi: 10.5367/oa.2015.0194 .

Kuehne, Llewellyn, Pannell, Wilkinson, Dolling, Ouzman, et al, (2017). Predicting farmer uptake of new agricultural practices: A tool for research, extension and policy." Agricultural Systems 156: 115-125. doi: 10.1016/j.agsy.2017.06.007.

Kuz, Y., Okwoche, V.A. and Age, A.I. (2018). The impact of national fadama III development project intervention on annual income generation among beneficiaries in Nasarawa State, Nigeria. Pyrex Journal of Plant and Agricultural Research, 3 (2), 6 - 10.

Laurens K. (2020) Advisory services and transformation, plurality and disruption of agriculture and food systems: towards a new research agenda for agricultural education and extension studies, The Journal of Agricultural Education and Extension, 26:2, 131140, DOI: $\underline{10.1080 / 1389224 X .2020 .1738046}$

Lewis, P. and Watts, M. (2015). Nigeria: The political economy of governance. Washington, DC: World Bank. Mansuri, Ghazala 
Creative Commons User License: CC BY-NC-ND

Abstracted by: EBSCOhost, Electronic Journals Service (EJS), Google Scholar, Journal Seek, Scientific Commons,

Food and Agricultural Organization (FAO), CABI and Scopus

http://eoi.citefactor.org/10.11226/v24i3
Journal of Agricultural Extension

Vol. 24 (3) July, 2020

ISSN(e): 24086851; ISSN(Print); 1119944X

http://journal.aesonnigeria.org

http://www.ajol.info/index.php/jae

Email: editorinchief@aesonnigeria.org

National Fadama Coordination Office, (NFCO), (2015). Third national Fadama development project- additional financing (Fadama III AF). Fadama III AF 3rd quarter progress report.

National Fadama Coordination Office, (NFCO), (2017). The Federal Government of Nigeria Third National Fadama Development Project (Fadama III) Additional Financing (AF) Credit No.: 52930-NG

Nwoye, I., \& Nwalieji, U. (2019). Male and female participation in the implementation of fadama III additional financing project among cassava farmers in Anambra State, Nigeria. Journal of Agricultural Extension, 23(4), 119129.

Osondu C. K., ljioma J. C., Udah S. C. and Emerole C. O. (2015). Impact of national Fadama III development project in alleviating poverty of food crop farmers in Abia State, Nigeria. American Journal of Business, Economics and Management. 3 (4), 225-233.

Sinkaiye, T., Nwserema, B., \& Ajayi, A. (2018). Application of livelihood analysis among farmers in amah community of river state Nigeria: Implication for extension agents training. Journal of Agricultural Extension, 11(01), 87-98. Retrieved from https://journal.aesonnigeria.org/index.php/jae/article/view/1642

Umeh, B.U. (2017). Participant farmers' access to components of Fadama III in Anambra State, Nigeria. (Masters thesis), Department of Agricultural Extension, University of Nigeria, Nsukka, $1-65$.

United States Agency for International Development, USAID (2015). Agricultural service providers: Finding sustainable models for strengthening livelihoods in an integrated project. USAID Community Connector Technical notes series No 5, August 2015.

World Bank (2016a). Implementation completion and results report: Third National Fadama Development Project.

World Bank (2016b). Nigeria - Third National Fadama Development Project:

Additional Financing and Restructuring Project Paper.

https://www.gtai.de/GTAI/Content/DE/Trade/Fachdaten/PRO/2016/08/Anlagen/ PRO201608185003.pdf?v=1

World Bank (2020) Nigeria - Second National Fadama Development Project: Environmental Assessment: Environmental and Social Impact Assessment (English). Washington, D.C. World Bank Group. http://documents.worldbank.org/curated/en/308131468759551052/Environmen tal-and-social-impact-assessmen 